Pace University

DigitalCommons@Pace

\title{
The Protection of the Marine Environment from Land-Based Pollution and Activities: Gauging the Tides of Global and Regional Governance
}

Ann Powers

Elisabeth Haub School of Law at Pace University

Follow this and additional works at: https://digitalcommons.pace.edu/lawfaculty

Part of the Environmental Law Commons, and the Water Law Commons

\section{Recommended Citation}

Ann Powers \& David L. VanderZwaag, The Protection of the Marine Environment from Land-Based Pollution and Activities: Gauging the Tides of Global and Regional Governance, 23 Int'l J. Marine \& Coastal L. 423 (2008), http://digitalcommons.pace.edu/lawfaculty/515/. 


\title{
The Protection of the Marine Environment from Land-Based Pollution and Activities: Gauging the Tides of Global and Regional Governance
}

\author{
David L. VanderZwaag \\ Director, Marine \& Environmental Law Institute, Dalhousie University \\ Canada Research Chair in Ocean Law and Governance \\ Co-chair of the IUCN Specialist Group on Oceans, Coasts and Coral Reefs \\ Ann Powers \\ Professor of Law, Pace Law School \\ Chair of the Land-based Marine Pollution/Activities Sub-group of the \\ IUCN Specialist Group on Oceans, Coasts and Coral Reefs
}

\begin{abstract}
After providing an introductory overview of the major land-based threats to the marine environment, this article focuses upon the specific global and regional efforts to address land-based marine pollution and activities through a four-part survey. The main international initiative is first described, namely, the Global Programme of Action for the Protection of the Marine Environment from Land-based Activities (GPA). Progress in GPA implementation is next assessed with an emphasis on the documentation and results from the Second Intergovernmental Review Meeting on Implementation of the GPA held in October 2006. Major challenges constraining GPA implementation are then summarized, including limited national participation, limited financing, and limits of a non-legally binding approach. Finally, regional agreements and initiatives to counter land-based marine pollution and activities are reviewed. Progress and challenges in GPA implementation at the regional seas level are highlighted.
\end{abstract}

\section{Keywords}

Land-based marine pollution, regional seas governance, sewage, nutrients, marine litter, alteration and destruction of habitats

\section{Introduction}

Land-based pollution and activities continue to be major threats to marine ecosystems. ${ }^{1}$ Some 80 per cent of pollution entering the oceans comes from

* The financial support of the Social Sciences and Humanities Research Council of Canada and the research assistance of Jason May are gratefully acknowledged.

${ }^{1}$ See generally, GESAMP (IMO/FAO/UNESCO-IOC/WMO/IAEA/UN/UNEP Joint Group 
land. ${ }^{2}$ Coastal area pressures, such as tourism developments, urbanization, industrial facility sitings, aquaculture, agriculture and deforestation, are common, with approximately 40 per cent of the world's population living within $100 \mathrm{~km}$ of the coast. ${ }^{3}$ Discharge of untreated sewage is widespread, especially in developing countries, where roughly 90 per cent of sewage may go into rivers and coastal waters without treatment. ${ }^{4}$ Nitrogen from fossil-fuel burning, fertilizer run-off and human and animal wastes has contributed to nutrient over-enrichment and excessive algal blooms in many marine regions. ${ }^{5}$ About 200 dead zones, areas of oxygen deprivation and devoid of life, are estimated to exist in coastal areas around the globe. ${ }^{6}$

The governance of human activities on land that have an impact on the marine environment is especially difficult to grasp. Regulation is largely left in the hands of over 125 coastal states with differing laws and policies. A fragmented array of international agreements and instruments has been forged which may assist in controlling land-based activities that adversely affect the oceans. ${ }^{7}$ For example, the UN Framework Convention on Climate Change ${ }^{8}$ and the Kyoto Protocol $^{9}$ seek to curb greenhouse gas emissions, which occur largely from land. Various conventions support the establishment of coastal protected areas. ${ }^{10}$ Two global agreements aimed at controlling chemicals and

of Experts on the Scientific Aspect of Marine Environmental Protection) and Advisory Committee on Protection of the Sea, Protecting the oceans from land-based activities: Land-based sources and activities affecting the quality and uses of the marine, coastal and associated freshwater environment, GESAMP Rep. Stud. No. 71 (2001), online: <http://gesamp.net/page. php?page $=3>$.

2 United Nations Environment Programme (UNEP), UNEP in 2006 (Nairobi, UNEP, 2007), online: <http://www.unep.org/pdf/annualreport/UNEP_AR_2006_English.pdf> at 56.

${ }^{3}$ T. Agardy et al., "Coastal Ecosystems," in: R. Hassan, M. Scholes and N. Ash (eds.) Ecosystems and Human Well-being: Current State and Trends: Findings of the Condition and Trends Working Group of the Millennium Ecosystem Assessment, The Millennium Ecosystem Assessment Series, Vol. 1 (Washington, D.C., Island Press, 2005) 513-549 at 515.

${ }^{4}$ UN-Water, Sanitation: a wise investment for health, dignity, and development (2008) at 6, online: <http://esa.un.org/iys/docs/IYS\%20Advocacy\%20kit\%20ENGLISH/Key\%20messages\% 20booklet.pdfs.

${ }_{5}$ UNEP and Woods Hole Research Center (WHRC), Reactive Nitrogen in the Environment: Too Much or Too Little of a Good Thing (Paris, UNEP, 2007).

${ }^{6}$ UNEP, Further Rise in Number of Marine 'Dead Zones', online: <http://www.unep.org/ Documents. Multilingual/ Default.asp? DocumentID $=486 \&$ ArticleID $=5393 \& 1=$ en $>$.

7 For a partial description, see D. Hassan, Protecting the Marine Environment from Land-based Sources of Pollution: Towards Effective International Cooperation (Burlington, VT: Ashgate Publishing Company, 2006) 76-87.

${ }^{8}$ New York, 9 May 1992. In force 21 March 1994, (1992) 31 I.L.M. 849.

9 Kyoto, 11 December 1997. In force 16 February 2005, (1998) 37 I.L.M. 22.

${ }^{10}$ For example, the Convention on Wetlands of International Importance especially as Waterfowl Habitat, 02 February 1971, 996 U.N.T.S. 245 [Ramsar] (entered into force 21 December 1975), 
toxic substances have been forged, ${ }^{11}$ in addition to other international initiatives such as the Strategic Approach to International Chemicals Management (SAICM). ${ }^{12}$ Various regional efforts have also been launched to address chemicals and heavy metals. ${ }^{13}$

The 1982 Law of the Sea Convention (LOSC), ${ }^{14}$ although having various provisions relevant to land-based marine pollution, does not contain detailed environmental standards ${ }^{15}$ and is largely aspirational. Article 207 requires states to adopt laws to prevent and control land-based sources of marine pollution and encourages states to establish global and regional rules and standards.

The governance picture is further complicated by the many guiding principles emerging in international environmental law relevant to landbased marine pollution and activities. ${ }^{16}$ Those principles include, among others, the precautionary principle/approach, ${ }^{17}$ pollution prevention, ${ }^{18}$ public

online: <http://www.ramsar.org/ key_conv_e.htm>; and the Convention on Biological Diversity, Rio de Janeiro, 5 June 1992. In force 29 December 1993, (1992) 31 I.L.M. 818.

11 Convention on the Prior Informed Consent Procedure for Certain Hazardous Chemicals and Pesticides in International Trade, Rotterdam, 10 September 1998. In force 24 February 2004, (1999) 38 I.L.M. 1; Stockholm Convention on Persistent Organic Pollutants, 23 May 2001. In force 17 May 2004, (2001) 40 I.L.M. 542.

12 SAICM is a voluntary international framework for fostering the sound management of chemicals, see online: <http://www.chem.unep.ch/saicm/>. For a brief review, see A. Logosasini, "Strategic Approach to International Chemicals Management: Lack of Interest Belies Importance," (2006) 6(3) Sustainable Development Law \& Policy 33-36.

13 For example, the protocols adopted under the auspices of the UN Economic Commission for Europe: Protocol on Persistent Organic Pollutants, Aarhus, 24 June 1998, in force 27 October 2003, online: <http://www.unece.org/env/lutap/pops_h1.htm>; and Protocol on Heavy Metals, Aarhus, 24 June 1998, in force 29 December 2003, online: <http://www.unece. org/env/lrtap/hm_h1.htm $>$. For a further review of regional and global efforts, see M. Pallemaerts, Toxics and Transnational Law: International and European Regulation of Toxic Substances as Legal Symbolism (Oxford, Hart Publishing, 2003).

14 Montego Bay, 10 December 1982. In force 16 November 1994, (1982) 21 I.L.M. 1261.

15 For a further critique of the general nature of land-based marine pollution obligations under LOSC, see A. Williams, "Reconciling Tourism and the Environment: A Task for International Environmental Law?” (2007) 9 Vermont J. Envtl. L. 23-70; and M. Qing-nan, Landbased Marine Pollution: International Law Development (London, Graham \& Trotman, 1987) $103-105$.

${ }^{16}$ For overviews, see P. Sands, Principles of International Environmental Law 2d ed. (Cambridge, Cambridge University Press, 2003); and S.A. Atapattu, Emerging Principles of International Environmental Law (Ardsley, N.Y., Transnational Publishers, Inc., 2006).

17 See, e.g., D. Freestone and E. Hey (eds.), The Precautionary Principle and International Law: The Challenge of Implementation (The Hague, Kluwer Law International, 1996); and S. Marr, The Precautionary Principle in the Law of the Sea: Modern Decision Making in International Law (The Hague, Martinus Nijhoff, 2003).

18 See, e.g., Nicolas de Sadeleer, Environmental Principles: From Political Slogans to Legal Rules (Oxford, Oxford University Press, 2002), 61-90. 
participation, ${ }^{19}$ environmental impact assessment, ${ }^{20}$ integration (including integrated pollution control) ${ }^{21}$ and polluter pays. ${ }^{22}$

International customary law and cases relating to transboundary harm from activities occurring within the territorial jurisdiction of a state affecting another state or states add a further layer to the land-based marine pollution/ activities governance "mosaic." ${ }^{3}$ The International Law Commission (ILC) has completed drafting of Articles on Responsibility of States for Internationally Wrongful Acts (2001) ${ }^{24}$ and Prevention of Transboundary Harm from Hazardous Activities (2001) ${ }^{25}$ which have codified various rules and principles relevant to transboundary pollution originating from land or threatening transboundary adverse effects from land-based activities. ${ }^{26}$ Two cases are currently before the International Court of Justice involving land-based pollution challenges that may further develop international jurisprudence relating to land-based environmental pollution responsibilities. ${ }^{27}$

Nevertheless, governance of land-based marine pollution and activities has been specifically targeted at both the global and regional levels. In 1995, 108 states and the European Commission adopted the Global Programme of Action for the Protection of the Marine Environment from Land-based Activities (GPA). ${ }^{28}$ The United Nations Environment Programme (UNEP) has encouraged regional addressing of land-based marine pollution and activities

19 See, e.g., B.J. Richardson and J. Razzaque, "Public Participation in Environmental Decisionmaking" in B.J. Richardson and S. Wood (eds.), Environmental Law for Sustainability (Portland, OR, Hart Publishing, 2006), 165-197.

20 See, e.g., Atapattu, op. cit., supra note 16, 289-378.

${ }^{21}$ See, e.g., D. VanderZwaag, Canada and Marine Environmental Protection: Charting a Legal Course Towards Sustainable Development (London, Kluwer Law International, 1995), 8-12.

22 See, e.g., de Sadeleer, op. cit., supra note 18, 21-60.

${ }^{23}$ For a review of principles, such as the principle of good neighbourliness, and key international cases, see Hassan, op. cit., supra note 7, 70-76.

${ }^{24}$ ILC, see online: <http://untreaty.un.org/ilc/texts/instruments/english/draft\%20articles/9_ 6_2002.pdf>.

${ }_{25}$ ILC, see online: <http://untreaty.un.org/ilc/texts/instruments/english/draft\%20articles/9_ 7_2001.pdf>.

${ }^{26}$ For example, the Articles on Prevention of Transboundary Harm from Transboundary Activities set out various procedural obligations for states, such as the requirements to authorize and environmentally assess activities under their jurisdiction that involve a risk of causing significant transboundary harm. Ibid., Arts. 6 and 7.

${ }_{27}$ The two proceedings include the Case Concerning Pulp Mills on the River Uruguay (Argentina $v$. Uruguay) and a case instituted on 31 March 2008 by Ecuador against Colombia for alleged aerial spraying by Colombia of toxic herbicides over Ecuadorian territory. See, ICJ, online: <http://www.icj-cij.org/homepage/index.php?lang=en>.

${ }^{28} \mathrm{UNEP(OCA)/LBA/IG.2/7} \mathrm{(5} \mathrm{December} \mathrm{1995)} \mathrm{[hereinafter} \mathrm{GPA],} \mathrm{online:} \mathrm{<http://www.}$ gpa.unep.org/>. 
through its Regional Seas Programme. ${ }^{29}$ The Programme currently covers 18 regional seas arrangements around the globe, ${ }^{30}$ with some of the regions having adopted specific protocols or annexes on land-based marine pollution and activities. ${ }^{31}$

This article focuses upon the specific global and regional efforts to address land-based marine pollution and activities through a four-part survey. The main international initiative to address land-based activities is first described, namely, the GPA. After progress in GPA implementation and its challenges are respectively discussed, a fourth part examines how land-based marine pollution and activities have been addressed at the regional level.

\section{The GPA}

While some countries and writers have supported the negotiation of a legally binding global agreement on land-based marine pollution and activities, ${ }^{32}$ the GPA, adopted in 1995, follows a "soft law" approach. ${ }^{33}$ The GPA seeks to guide states in how to address land-based activities affecting the marine environment at three levels - national, regional and global. A brief sketch of some of the main provisions follows.

\section{National}

Chapter 2 of the GPA urges states to develop national programmes of action (NPAs) within a few years ${ }^{34}$ and suggests basic parameters to be followed. These NPAs are encouraged to follow a six-part format: 1) identifying and assessing problems; 2) establishing priorities for action; 3) setting management objectives for priority problems; 4) selecting management strategies and measures; 5) including criteria for evaluating the effectiveness of management interventions; and 6) ensuring programme support elements, such as financing,

29 The Programme, launched in 1974, encourages states surrounding shared marine waters to cooperate through regional seas programmes. UNEP, The Regional Seas Programme, online: <http://www.unep.org/regionalseas/>.

30 UNEP, The Regional Seas Programmes, online: <http://www.unep.org/regionalseas/ Programmes/ default.asp $>$.

31 See infra., note 142.

32 See Hassan, op. cit., supra note 7, 179-206.

33 On the role of non-legally binding documents, see P.W. Birnie and A.E. Boyle, International Law and the Environment, 2d ed. (Oxford, Oxford University Press, 2002) 24-27.

34 GPA, op. cit., supra note 28, para. 19. 
human resources and legal and enforcement mechanisms. ${ }^{35}$ Key principles that NPAs should follow include integrated coastal area management, public participation, poverty alleviation, environmental impact assessment, the precautionary approach and intergenerational equity. ${ }^{36}$

Chapter 5 further suggests that states set specific targets and take various actions in relation to nine source categories (sewage, persistent organic pollutants (POPs), radioactive substances, heavy metals, oils (hydrocarbons), nutrients, sediments, litter and physical alterations and destruction of habitats). For example, various proposed targets are set out for sewage, such as the aim to dispose of all sewage by the year 2025 in conformity with national or international environmental quality guidelines. ${ }^{37}$ Sewage actions urged, among others, include promotion of primary, secondary and, where appropriate, tertiary treatment of managed sewage; identification of productive uses of sewage, like land-spreading and composting; implementation of no-water or low-water solutions; and improvement of local or national regulatory and monitoring programmes. ${ }^{38}$

\section{Regional}

Chapter 3 of the GPA seeks to enhance regional cooperation in protecting the marine environment from land-based activities. States are encouraged to strengthen existing regional conventions and programmes and to consider negotiating new regional conventions and programmes. ${ }^{39}$ Development of regional programmes of action, modelled on the six-part format for national programmes, is also suggested. ${ }^{40} \mathrm{~A}$ checklist of points to consider in a regional programme is provided, for example, harmonization of pollutant discharge standards, protection of coastal habitats and endangered species, use of innovative financing mechanisms and provision for capacity-building. ${ }^{41}$

Chapter 5 suggests possible targets and actions to be taken within regional programmes of action. For example, states are encouraged to develop regional exchanges of information and advice regarding environmentally sound sewage treatment. ${ }^{42}$

35 Ibid., para. 18.

36 Ibid., para. 23.

37 Ibid., para. 96.

38 Ibid., para. 97.

39 Ibid., para. 31.

40 Ibid., para. 32.

41 Ibid., para. 33.

42 Ibid., para. 98. 


\section{International}

Chapter 4 is partly devoted to the challenge of mobilizing international financial resources to support development and implementation of national and regional programmes of action. The chapter emphasizes that, in general, states are expected to finance their national and regional programmes from their own public and private sectors. ${ }^{43}$ Aspirational funding objectives include an acknowledgement that substantial new and additional funding will be required for countries in need of assistance, ${ }^{44}$ a general plea to financial institutions (national, international and bilateral donors) to assist with capacitybuilding $^{45}$ and an invitation to the Global Environment Facility (GEF) to support GPA implementation under its various focal areas, especially international waters and biodiversity protection. ${ }^{46}$

Besides urging development of international legally binding instruments for $\mathrm{POPs}^{47}$ and a prior informed consent procedure for certain hazardous chemicals in trade ${ }^{48}$ (which in fact subsequently occurred), Chapter 4 set the institutional foundation for coordinating future international cooperation. UNEP was given the secretariat role and urged to provide GPA implementation through a revitalized Regional Seas Programme. ${ }^{49}$ Convening of periodic intergovernmental review meetings to assess progress and consider reports on national plans was also recommended. ${ }^{50}$

\section{Progress in GPA Implementation}

Although gauging progress in GPA implementation is difficult to fathom in light of so many states and international organizations and initiatives trying to address the multiple facets of land-based marine pollution, ${ }^{51}$ the Second

\footnotetext{
43 Ibid., para. 51.

44 Ibid., para. 51(b).

45 Ibid., para. 61.

46 Ibid., para. 69.

47 Ibid., para. 88 .

48 Ibid., para. 90.

49 Ibid., para. 74.

50 Ibid., para. 77.
}

${ }^{51}$ For a summary of earlier progress, see UNEP, Report of the First Intergovernmental Review Meeting on the Implementation of the Global Programme of Action for the Protection of the Marine Environment from Land-based Activities, Montreal, Canada, 26-30 November 2001, UNEP/ GPA/IGR.1/9 [IGR-1 Report], online: <http://www.gpa.unep.org/documents/igr1_official_ report_english.pdf $>$. 
Intergovernmental Review Meeting on Implementation of the Global Programme of Action for the Protection of the Marine Environment from Landbased Activities (IGR-2), held in Beijing, 16-20 October 2006, provided some readings into how implementation is faring. ${ }^{52}$ The meeting also facilitated publication of further guidance and strategy documents. Subsequent initiatives have also followed, including the declaration by the UN General Assembly of 2008 as the International Year of Sanitation. ${ }^{53}$

\section{The Second Intergovernmental Review Meeting on Implementation of the GPA}

Besides reviewing progress in GPA implementation at the level of regional seas, ${ }^{54}$ the IGR-2 facilitated assessments of how the nine land-based threats targeted by the GPA have been curbed, or not, in relation to the marine environment, and the status of national and international activities. Further guidance on national and international implementation was also given through guidance documents and the Beijing Declaration on Furthering the Implementation of the Global Programme of Action for the Protection of the Marine Environment from Land-based Activities (Beijing Declaration). ${ }^{55}$

\section{Review of the State of the Marine Environment}

A report, The State of the Marine Environment: Trends and Processes, ${ }^{56}$ prepared for the IGR-2, assessed the status of actions for addressing each of the nine GPA source categories with an overall conclusion that GPA implementation has been uneven. Good progress was reported for three categories-POPs, radioactive substances and oils (hydrocarbons). Mixed results summarized the reality for heavy metals and sediment mobilization. Four categories showed worsening conditions, specifically, sewage, nutrients, marine litter and physical alteration and destruction of habitats, and the sources were highlighted as future priorities for action. ${ }^{57}$

52 See UNEP, Report of the second session of the Intergovernmental Review Meeting on the Implementation of the Global Programmes of Action for the Protection of the Marine Environment from Land-based Activities, UNEP/GPA/IGR-2/7 [Report of IGR-2], online: <http://www.gpa. unep.org/documents/igr-2_final_meeting_report_english.pdf>.

53 UNGA Res. 61/192, International Year of Sanitation, 2008, online: <http://daccessdds. un.org/doc/UNDOC/GEN/N06/505/95/PDF/N0650595.pdf?OpenElement>.

${ }_{54} \mathrm{UNEP} / \mathrm{GPA}$, Implementation of the GPA at regional level: The role of regional seas conventions and their protocols (The Hague, UNEP/GPA, 2006).

55 IGR-2 Report, op. cit., supra note 52, Annex V [Beijing Declaration].

$56 \mathrm{UNEP/GPA}$, The State of the Marine Environment: Trends and Processes (The Hague, UNEP/ GPA, 2006) [Trends Report].

57 Ibid. at iv. 
Sewage was described as the area where least progress has been achieved, with population growth outpacing treatment facilities and infrastructure. The percentage of waste water discharged untreated was estimated for various regions with considerable variability, ranging from 10 per cent in the North Atlantic to 89 per cent in East Asia. ${ }^{58}$

Nutrient over-enrichment, while varying region to region, ${ }^{59}$ was highlighted as a common concern. Eutrophication has affected large areas of semi-enclosed seas, including the Baltic, North Adriatic and Black Seas in Europe, the Gulf of Mexico, and the Seto Inland Sea in Japan. ${ }^{60}$ Over 600,000 tonnes of nitrogen are deposited annually via rivers running through Cambodia, China, Malaysia, Thailand and Vietnam to marine waters above the Sanda Shelf. ${ }^{61}$ In North America, nitrogen fluxes in the Mississippi River have increased fourfold and in rivers in the northeast eight-fold. ${ }^{62}$ An estimated 2.4-2.7-fold increase by 2050 in nitrogen and phosphorus-driven eutrophication was predicted for terrestrial, freshwater and near-shore marine ecosystems because of increasing demands for food for an expanding global population. ${ }^{63}$

Marine litter was determined to be a further priority. Plastic litter, besides being a source of persistent toxic substances and a vehicle for transporting exotic invasive species over long distances, is estimated to kill more than 1 million birds and 100,000 marine mammals and sea turtles each year. ${ }^{64} \mathrm{An}$ annual coastal cleanup event in 2002 involving volunteers in some 100 countries collected 6.2 million pieces of refuse weighing 4,000 tonnes, with nearly 58 per cent of the litter attributable to recreational activities along the shore. ${ }^{65}$ Millions of tonnes of military debris, such as old munitions, have also been dumped in the oceans. ${ }^{66}$

Physical alteration and destruction of habitats were also identified as one of the top four priorities. Some 50 per cent of all wetlands and over 50 per cent of mangroves have been lost over the past century and 30 per cent of the world's coral reefs have been described as seriously damaged. ${ }^{67}$ Pressures on coastal habitats are expected to increase in light of growing populations and

\footnotetext{
58 Ibid. at 4.

59 For a table comparing nitrogen concentrations by region, see Ibid. at 20 .

60 Ibid.

${ }^{61}$ Ibid. at 21.

62 Ibid.

63 Ibid. at 33.

${ }^{64}$ Ibid. at 27.

65 Ibid.

66 Ibid.

67 Ibid. at 29.
} 
migration patterns, with population densities in the coastal zone projected to increase from 99 persons $/ \mathrm{km}^{2}$ in 2010 to $134 \mathrm{p} / \mathrm{km}^{2}$ in $2050 .{ }^{68}$

The 2006 report also identified a set of emerging land-based marine pollution/activity challenges. They include, among others, depleted freshwater flows to the oceans, hundreds to thousands of new chemicals released into the environment, heavy metals and other contaminants from electronic wastes, and the effects of sea level rise. ${ }^{69}$

\section{Progress in National Implementation}

A 2006 progress report on GPA implementation ${ }^{70}$ highlighted that over 60 countries are implementing the GPA either through specific NPAs or through related processes. ${ }^{71}$ Those processes include, among others, national development policies and frameworks and integrated coastal management programmes.

Although the initial strategy of the UNEP Global Programme of Action Coordination Office was to support individual countries in developing national programmes, the Coordination Office has moved to a "partnership approach." A partnership forged with regional sea secretariats has advanced national programme of action developments within particular regions, including the South-East Pacific, the Wider Caribbean, the Caspian, the South Pacific and South Asia. ${ }^{72}$ A partnership with the International Program Office of the United States of America's National Oceanic and Atmospheric Administration (NOAA) has established a GPA node within NOAA to support GPA implementation in countries of Central America and the Caribbean. ${ }^{73}$ The GEF has also supported national programme of action processes through various projects including, among others, "Addressing land-based activities in the Western Indian Ocean project" (Eastern Africa) and the "Combating living resources depletion and coastal area degradation in the Guinea current large marine ecosystem through ecosystem-based regional actions project" (Western and Central Africa). ${ }^{74}$

68 Ibid. at 28.

${ }^{69}$ Ibid. at 34-35.

${ }^{70}$ UNEP, Progress in implementing the Global Programme of Action for the Protection of the Marine Environment from Land-based Activities at the international, regional and national levels in the period 2002-2006, UNEP/GPA/IGR-2 [Progress Report], online: <http://www.gpa. unep.org/documents/progress_in_implementing_the_gpa_2_english.pdf>.

71 Ibid. at 4.

72 Ibid. at 6.

73 Ibid. at 7.

74 Ibid. 


\section{Progress in International Implementation}

The 2006 progress report on GPA implementation highlighted how various international fora have urged or supported GPA implementation. For example, at the World Summit on Sustainable Development in 2002, world leaders through the Johannesburg Plan of Implementation urged "advanced implementation" of the GPA, with particular emphasis for the period 2002 to 2006 on municipal wastewater, the physical alteration and destruction of habitats, and nutrients. ${ }^{75}$ The 2005 International Meeting to Review the Implementation of the Programme of Action for the Sustainable Development of Small Island Developing States adopted the Mauritius Strategy for the Further Implementation of the Programme of Action for the Sustainable Development of Small Island Developing States, and the Strategy urges collaboration among small island developing states, international development partners and UNEP to fully implement the GPA. ${ }^{76}$ The Commission for Sustainable Development has adopted various decisions of relevance to the GPA, including at its thirteenth session in 2005 , the need to promote integrated water resources management and to strengthen prevention of pollution from wastewater, solid waste, and industrial and agricultural activities. ${ }^{77}$ The UN General Assembly has also issued resolutions supportive of GPA implementation, for example, Resolution 60/30 urges capacity-building for developing states to implement improved waste management practices. ${ }^{78}$

The 2006 progress report also noted the numerous partnerships the UNEP GPA Coordination Office has supported or launched that support GPA implementation discussions and project activities. Those partnerships include, among others, the Global Forum on Ocean Coasts and Islands, White Water to Blue Water, Hilltop to Oceans, Partnership in Environmental Management for the Seas of East Asia, and GEF funding of 18 large marine ecosystem

75 Para. 33, see online: <http://www.un.org/esc/sustdev/documents/WSSD_POI_PD/English/WSSD_PlanImpl.pdf>.

${ }_{76}$ Report of the International Meeting to Review the Implementation of the Programme of Action for the Sustainable Development of Small Island Developing States, Port Louis, Mauritius, 10-14 January 2005, 32 A/Conf. 207/11, Annex II, para. 32, online: <http://daccessdds.un.org/doc/ UNDOC/GEN/N05/489/34/PDF/N0548934.pdf?OpenElement>.

77 UN Commission on Sustainable Development, Report of the Thirteenth Session (30 April 2004 and 11-22 April 2005), Economic and Social Council Official Records, 2005, Supp. No. 9, Resolution 13/1, online: <http://daccessdds.un.org/doc/UNDOC/GEN/N05/382/16/ PDF/N0538216.pdf?OpenElement>.

78 UNGA Resolution 60/30 on Oceans and the Law of the Sea, 29 November 2005, para. 12, online: <http://daccessdds.un.org/doc/UNDOC/GEN/N05/489/34/PDF/N0548934.pdf?Open Element>. 
projects having land-based marine pollution components as well as other investment commitments. ${ }^{79}$

Various international initiatives have also been launched in relation to priority issues, particularly municipal wastewater. A Strategic Action Plan on Municipal Wastewater has been jointly developed by UNEP, the United Nations Human Settlements Programme (UN-Habitat), the Water Supply and Sanitation Collaborative Council, and the World Health Organization. ${ }^{80}$ In addition, Guidelines on Municipal Wastewater Management have been produced, providing practical guidance on how to plan and finance environmentally sound municipal wastewater discharge systems. ${ }^{81}$

\section{Further Guidance on National and International Implementation}

Three main documents, linked to the IGR-2, provide further guidance on GPA implementation. A guide for national action, ${ }^{82}$ replacing an earlier handbook on national programme of action implementation, ${ }^{83}$ describes key management approaches ${ }^{84}$ and principles ${ }^{85}$ explains steps and tasks to be followed in national planning processes ${ }^{86}$ and provides background references and documents, including a complete list of the Millennium Development Goals (MDGs) along with targets and indicators. ${ }^{87}$

Guidance on Implementation of the GPA for 2007-2011 is a second document that was revised following discussion at IGR-2. ${ }^{88}$ After setting out the

79 Progress Report, op. cit., supra note 70, paras. 40-47.

${ }^{80} \mathrm{UNEP} / \mathrm{WHO} / \mathrm{HABITAT} / W S S C C$ Strategic Action Plan on Municipal Wastewater (The Hague, UNEP/GPA, 2001).

${ }^{81}$ UNEP/GPA, Guidelines on Municipal Wastewater Management (The Hague, UNEP/GPA Coordination Office, 2004).

${ }^{82} \mathrm{UNEP} / \mathrm{GPA}$, Protecting coastal and marine environments from land-based activities: A guide for national action (The Hague, UNEP/GPA, 2006) [hereinafter NPA Guide].

83 UNEP, Handbook on the Development and Implementation of a National Programme of Action for the Protection of the Marine Environment from Land-based Activities (The Hague, UNEP/ GPA Coordination Office, 2002).

${ }^{84}$ Approaches include, among others, integrated water resources management (IWRM), integrated coastal area and river basin management (ICARM) and community-based natural resource management (CBNRM). NPA Guide, op. cit., supra note 82, 10-14.

85 Principles include, among others, stakeholder involvement, and precaution and transparency. Ibid. at 20-30.

${ }^{86}$ Flexibility is suggested whereby some states already quite far advanced in addressing landbased activities in an integrated way may choose not to develop a full NPA. Ibid. at 32-36.

87 Ibid. at Annex 4. Especially relevant to the GPA is the MDG target of halving by 2015 the proportion of people without sustainable access to safe drinking water and basic sanitation. Ibid. at 83.

88 UNEP, Guidance on the implementation of the Global Programme of Action for the Protection of the Marine Environment from Land-based Activities for 2007-2011: Global Programme of 
international legal, policy, financial and conceptual frameworks relevant to the GPA, the document suggests various approaches that governments may wish to follow, including the ecosystem approach, integrated water resources management, internalization of environmental and economic value of goods and services provided by oceans, coasts and associated watersheds, and the " $3 \mathrm{R}$ " approach (reduce, reuse and recycle). ${ }^{89}$ Actions suggested at the national level include, among others, prioritizing objectives and targets in national GPA programmes and projects in order to address internationally agreed development goals ${ }^{90}$ revising relevant financing and legislative instruments for water, coastal and marine management, and implementing multilateral environmental agreements relevant to the GPA more effectively. ${ }^{91}$ Suggested international cooperation actions include, among others, inviting the GEF, international financial institutions and bilateral assistance organizations to increase support for protection of the marine environment from land-based activities, increasing collaboration between the UNEP/GPA Coordination Office and various freshwater initiatives and related institutions, ${ }^{92}$ and promoting greater coordination between the GPA and regional seas conventions and action plans, as well as with GPA-related multilateral environmental agreements. $^{93}$

The Beijing Declaration, adopted at the IGR-2, also urged various actions. For example, representatives called for mainstreaming the objectives of the GPA into national development planning and legislation, application of the ecosystem and integrated management approaches, and effective national implementation of international and regional conventions and protocols relevant to the GPA. ${ }^{94}$ Developing and strengthening implementation of regional protocols addressing land-based pollution sources and activities was also resolved..$^{95}$ A plea was also made to international and regional financial institutions and donor countries to increase their contributions in support of capacitybuilding in developing countries and implementation of their NPAs. ${ }^{96}$

Action contribution to the internationally agreed goals and targets for the sustainable development of oceans, coasts and islands. Revision Post IGR-2 (December 2006), online: <http://www.gpa. unep.org/documents/revised_guidance_document_post_english.pdf $>$.

89 Ibid. at paras. 119-122.

${ }_{90}$ For example, goals contained in the Millennium Declaration and the Johannesburg Plan of Implementation. Ibid. at para. 126.

91 Ibid. at para. 125.

92 Such as the Global Water Partnership, the International Network of Basin Organisations and UN-Water. Ibid. at para. $132(\mathrm{~g})$.

93 Ibid. at para. 132(f).

94 Beijing Declaration, op. cit., supra note 55, paras. 4-9.

95 Ibid. at para. 15.

96 Ibid. at para. 18. 
Initiatives and Developments Post-IGR-2

UN General Assembly resolutions on oceans and the law of the sea following IGR-2 have kept the GPA on the international agenda. Resolution 61/222 adopted in December 2006 welcomed the outcomes from IGR-2 and called upon states to take all appropriate measures to fulfill the commitments embodied in the Beijing Declaration. ${ }^{97}$ Resolution 62/215, adopted in December 2007, welcomed continued work by states, UNEP and regional organizations in GPA implementation and encouraged increased emphasis on the link between freshwater, the coastal zone and marine resources, and implementation of international development goals, such as the target on sanitation. ${ }^{98}$

Various efforts to better address nutrient over-enrichment of coastal and marine ecosystems have been initiated. In June 2007, the UNEP/GPA Coordination Office in partnership with the Ministry of the Environment of the Government of the Netherlands and the UNEP Division of Technology, Industry and Economics launched the Global Partnership on Nutrient Management. The partnership's objectives are to raise awareness and disseminate information about nutrient over-enrichment, to exchange good practice experiences and to encourage cooperative actions. ${ }^{99}$ The GEF under its international waters focal area for funding has included reduction of nutrient enrichment as one of five strategic programme areas for 2007-2010. The objective is to assist in reducing nutrient over-enrichment and oxygen depletion from land-based pollution of coastal waters in large marine ecosystems (LMEs) consistent with the GPA. Initial efforts are expected to focus on landbased nutrient pollution reduction in East Asian LMEs and the Mediterranean Sea LME. ${ }^{100}$

${ }_{97}$ Oceans and the Law of the Sea, GA Res. 61/222, UN GAOR, 61st Sess., UN Doc. A/ Res/61/222 (2007) para 71, online:<http://www.un.org/ga/search/view_doc.asp?symbol=A/ $\mathrm{RES} / 61 / 222 \& \mathrm{Lang}=\mathrm{E}>$.

98 Oceans and the Law of the Sea, GA Res. 62/215, UN GAOR, 62nd Sess., UN Doc. A/ Res/62/215 (2008) para 96, online: <http://daccessdds.un.org/doc/UNDOC/GEN/N07/476/ 67/PDF/N0747667.pdf?OpenElement $>$.

${ }^{99}$ UNEP/GPA, Global Partnership on Nutrient Management, available online: <http://www. gpa.unep.org/ content.html? $\mathrm{In}=6 \& \mathrm{id}=385>$. Various documents have already been disseminated, including UNEP and WHRC, Reactive Nitrogen in the Environment: Too Much or Too Little of a Good Thing (Paris, UNEP, 2007) and International Fertilizer Industry Association, Sustainable Management of the Nitrogen Cycle in Agriculture and Mitigation of Reactive Nitrogen Side Effects (Paris, International Fertilizer Industry Association, 2007).

100 GEF, International Waters Focal Area Strategy and Strategic Programming for GEF-4, see online: <http://www.thegef.org/uploadedFiles/Policies/Focal_Area_Strategies/GEF_4_strategy_ IW_revision2_March_6_08.pdf>. 
In 2007, the UNEP/GPA Coordination Office updated its website. A database on the status of national programme of action processes is available online. ${ }^{101}$

With the UN General Assembly declaring 2008 as the International Year of Sanitation, various initiatives have emerged. The UNEP/GPA Coordination Office, as a member of the UN-Water Task Force on the International Year of Sanitation, is working with other UN agencies and international organizations to raise awareness on sanitation issues in order to accelerate progress toward the MDG target of reducing by half the proportion of people without access to basic sanitation by 2015. ${ }^{102}$ A dedicated website for the International Year of Sanitation has been established ${ }^{103}$ and various publications are available online. ${ }^{104}$

\section{GPA Challenges}

The challenges constraining effective protection of the marine environment from land-based pollution and activities are common to many areas of environmental governance. Those challenges include, among others: poverty, lack of public education and awareness, limited individual and political wills to take pollution and environmental degradation seriously, over-consumption and materialistic mindsets, limited financial and human resources, fragmented legal and institutional arrangements, and lack of effective compliance and enforcement. ${ }^{105}$

Many of the shortcomings of the GPA, identified not long after its adoption, still hold true. ${ }^{106}$ Six key challenges facing GPA implementation include:

$101 \mathrm{UNEP} / \mathrm{GPA}$, List and status of ongoing NPA processes, see online: <http://www.gpa.unep. org/Content.html? $1 \mathrm{n}=6 \& \mathrm{id}=331>$.

102 UNEP/GPA, Latest news (31 October 2007), see online: <http://www.gpa.unep.org/news. html>.

$\overline{103}$ See online: <http://www.sanitationyear2008.org>.

104 See, e.g., UN-Water, Sanitation: A wise investment for health, dignity, and development (2008); and World Health Organization and UNICEF, Meeting the MDG drinking water and sanitation target: the urban and rural challenge of the decade (2006).

105 For a review of some of the main challenges, see D.M. Johnston and D.L. VanderZwaag, "The ocean and international environmental law: swimming, sinking and treading water at the millennium," (2001) 43 Ocean \& Coastal Management 141-161.

106 For example, lack of clear and specific international targets and environmental standards, and a preference for generalities. See D.L. VanderZwaag, P.G. Wells and J. Karau, "The Global Programmes of Action for the Protection of the Marine Environment from Land-based Activities: A Myriad of Sounds, Will the World Listen?” (1998) 13 Ocean Yearbook 183-210. 
limited national participation and implementation, limited national reporting, limited coverage of pollutant source categories, limited financing, limits of a non-legally binding approach, and limits in international environmental governance.

\section{Limited National Participation and Implementation}

Participation by countries in GPA processes has not been universal. While 108 states took part in the 1995 International Conference to adopt the GPA, ${ }^{107}$ representatives from only 98 countries participated at the 2001 First Intergovernmental Review Meeting on GPA Implementation in Montreal ${ }^{108}$ and representatives of 104 governments joined IGR-2 in Beijing. ${ }^{109}$

Development and implementation of NPAs, while progressing, still have a long way to go. According to the UNEP/GPA Coordination Office, more than 60 NPAs are being planned, developed or implemented around the globe, but many countries have yet to at least formally embrace the NPA process. For example, as of July 2007 only two East Asian states, China and the Republic of Korea, were listed as involved in the NPA process. ${ }^{110}$

\section{Limited National Reporting}

In the lead-up to IGR-2, countries were invited to participate in a voluntary reporting exercise on progress in GPA implementation. However, only 14 national reports were submitted to the secretariat. ${ }^{111}$

While useful in identifying some of the major constraints ${ }^{12}$ and lessons learned ${ }^{113}$ in NPA implementation, the national reports tended to be very sketchy.

107 UNEP/GPA, The Global Programme of Action for the Protection of the Marine Environment from Land-based Activities, online: <http://www.gpa.unep.org>.

108 IGR-1 Report, op. cit., supra note 51.

109 IGR-2 Report, op. cit., supra note 52.

110 UNEP/GPA, op. cit., supra note 101. It should be noted that the number of countries involved in NPA development and implementation efforts has more recently been listed as over 70. See UNEP, UNEP 2007 Annual Report at 44, online: <http://www.unep.org/PDF/ AnnualReport/2007/AnnualReport2007_en_web.pdf>.

${ }_{111}$ UNEP, Summary report on voluntary national reporting on the implementation of the Global Programme of Action for the Protection of the Marine Environment from Land-based Activities, UNEP/GPA/IGR.2/INF/2, online: <http://www.gpa.unep.org/documents/igr-2_information_ document_2_english.pdf>.

$\overline{112}$ For example, lack of financial resources, limited managerial and technical capacity, lack of available data and information, inadequate institutional arrangements and limited control over local land uses. Ibid. at paras. 36 and 37.

113 For example, importance of broad stakeholder involvements, need for high-level political 
For example, a common approach was to simply list relevant departments/ agencies, laws and guidelines, and projects relevant to the GPA without any detailed or critical comment. Whether projects listed were in fact actually linked to NPA processes was also not always clear.

The national reporting process, besides being just voluntary, was also weak on other fronts. No independent review process was established to vet and comment on national reports. Lack of guidance on indicators for measuring success of NPA processes has also been identified as a limitation. ${ }^{114}$

\section{Limited Coverage of Pollutant Source Categories}

While the GPA has covered a large portion of land-based marine pollutants through its nine source categories, two challenges falling outside the categories stand out. A first challenge is addressing the hundreds to thousands of chemicals released into the environment that may be toxic but fall outside the limited POP "box." 115 In particular, little is known about the effects of personal care products and pharmaceuticals on components of aquatic ecosystems. ${ }^{116}$

A second pollutant category is carbon emissions from land-based sources. Other than a mention of the UN Framework Convention on Climate Change as one of the conventions important for the protection of the marine environment $^{117}$ and an urging that states consider whether atmospheric depositions are a problem and priority, ${ }^{118}$ the GPA is silent about climate change. The role of the GPA in studying and addressing climate change impacts on coastal and freshwater ecosystems remains uncertain, and at least one country has noted that the issue warrants further consideration. ${ }^{119}$

\section{Limited Financing}

Since its inception, the GPA has struggled to mobilize financial resources. The founding document did not provide for a new dedicated international fund or

support and endorsement and the use of pilot projects to foster local partnership. Ibid. at paras. 40-42.

114 Ibid. at para. 51.

115 Trends Report, op. cit., supra note 56 at 35.

116 UN World Water Assessment Programme, Water a shared responsibility: The United Nations World Development Report 2 (Paris: UNESCO, 2006) at 180.

117 GPA, op. cit., supra note 28, para. 7.

118 Ibid., para. 21(d)(iii).

119 See National Programme of Action Secretariat (Canada), Implementing Canada's National Programme of Action for the Protection of the Marine Environment from Land-based Activities, online: <http://www.npa-pan.ca.en/publications/overview_poster/overview.cfm>. 
funds and emphasized that, in general, financing implementation of national and regional programmes should come from each country's own public and private sectors. ${ }^{120}$ An illustrative list of funding sources and mechanisms was provided. $^{121}$

Getting a precise picture of implementation funding is difficult. A large number of donors fund a diffuse array of projects and activities at national and regional levels. The UNEP/GPA Coordination Office provides only general information on funding. It highlights that the Coordination Office is primarily funded through the regular budget of UNEP (Environment Fund) and a Technical Co-operation Fund financed by various governments, while a General Trust Fund, depending on voluntary financial contributions, supports implementation activities. ${ }^{122}$

Financing for GPA implementation clearly has not been adequate. The Beijing Declaration highlighted the continued insufficiency of funding for GPA implementation in developing countries and called upon international and regional financial institutions and donor countries to increase contributions to support countries in developing and implementing their NPAs. ${ }^{123}$ Limited GPA financing has also been a reality for some developed states. ${ }^{124}$

Financing to support adequate sanitation and wastewater treatment remains a particular challenge. According to one estimate, just to meet the MDG goal of halving by 2015 half of the proportion of people without access to basic sanitation will require, over a ten-year period, US $\$ 142$ billion for new sanitation coverage and US $\$ 216$ billion for maintaining existing sanitation infrastructure and services. ${ }^{125}$ The control of pollution from sewage, particularly in developing countries, has been recognized as perhaps the most serious of problems within the GPA framework and the area where least progress has been achieved. ${ }^{126}$

\footnotetext{
${ }^{120}$ GPA, op. cit., supra note 28, para. 51.

121 Ibid., Annex.
}

$122 \mathrm{UNEP} / \mathrm{GPA}$, Funding of the Activities of the UNEP/GPA Coordination Office, see online: <http://www.gpa.unep.org/print.html?id=186\&1n=6>.

123 Beijing Declaration, op. cit., supra note 55, para. 18.

${ }^{124}$ For example, see Canada's NPA Progress Report, online: <http://www.gpa.unep.org/documents/national_report_Canada_english.pdf>.

125 See C. Hutton and J. Bartram, Regional and Global Costs of Attaining the Water Supply and Sanitation Target (Target 10) of the Millennium Development Goals, WHO/HSE/AMR/08/01 (Geneva, World Health Organization, 2008). Estimates on financing needed to meet the international sanitation target vary considerably, with another common estimate being some USD 56 billion required annually for wastewater treatment. See G. Nellemann, S. Hain and J. Alder (eds.), In Dead Water-Merging of climate change with pollution, over-harvest, and infestations in the world's fishing grounds (Norway, UNEP, GRID-Arendal, 2008), at 42.

126 Trends Report, op. cit., supra note 56, at 5. 


\section{Limits of a Non-Legally Binding Approach}

The "soft law" nature of the GPA has been identified as a substantial limitation. For example, Canada's voluntary national report for IGR-2 noted the reality that while the non-legally binding GPA gives flexibility, it does not provide a mechanism to ensure actions are taken. ${ }^{127}$ On the academic front, negotiation of a global legally binding agreement to better address land-based marine pollution has been urged in order to overcome many of the weaknesses latent in a voluntary and aspirational approach. ${ }^{128}$ Elements of such an agreement might include, among others, a process for developing detailed and enforceable pollution standards, obligatory funding commitments to support capacity-building and technology transfers to developing countries, encouragement of public participation and education, inclusion of a compliance mechanism, and a specific dispute resolution procedure for land-based marine pollution conflicts. ${ }^{129}$

Moving from the GPA to a treaty-based approach does not seem likely, at least in the near term. Consideration of the need for a new legally binding instrument on land-based marine pollution has not been on the political agenda. No formal discussions of the issue occurred at the two previous GPA intergovernmental review meetings. Reaching consensus on the need for an agreement would be difficult since some countries believe land-based marine pollution can most effectively be addressed at national and regional levels. ${ }^{130}$

\section{Limits in International Environmental Governance}

While the GPA continues to be implemented at national, regional and global levels, the GPA does not "swim alone", and the long-term success in protecting the marine environment from land-based activities may depend on progressive steps formed in the broader context of international environmental governance. Those progressions include, among others, further reducing greenhouse gas emissions, ${ }^{131}$ addressing population growth, ${ }^{132}$ getting a more

\footnotetext{
127 See Canada's NPA Report, op. cit., supra note 110.

128 Hassan, op. cit., supra note 7, 182-196.

129 Ibid. at 197-206.

130 VanderZwaag, Wells and Karau, op. cit., supra note 106, at 208.

131 See, e.g., M. Doelle, From Hot Air to Action? Climate Change, Compliance and the Future of International Environmental Law (Toronto, Thomson Canada Limited, 2005).

132 See, e.g., R. Engelman, More: Population, Nature and What Women Want (Washington D.C., Island Press, 2008).
} 
comprehensive grip on chemicals management, ${ }^{133}$ further curbing emission of heavy metals, (including mercury), ${ }^{134}$ and strengthening the overall global framework for environmental governance, for example, through a strengthened and well-financed UNEP. ${ }^{135}$

\section{UNEP's Regional Seas Programme and GPA Implementation}

\section{Framework}

The Regional Seas Programme (RSP), established in 1974 following the 1972 UN Conference on the Human Environment, aims to reduce the degradation of the world's seas by encouraging comprehensive cooperative efforts and specific actions by nations which share those waters. It has been described as a global programme with regional components ${ }^{136}$ and has over time fostered a

133 For example, a new global agreement placing the burden of proof at least on proponents of new chemical introductions into commerce to demonstrate a standard of safety and moving towards a reverse listing approach whereby only chemicals on a global "safe list" could be marketed. See D. VanderZwaag, Book Review of Protecting the Marine Environment from Landbased Sources of Pollution: Towards Effective International Cooperation by D. Hassan, (2007) 12 Ocean and Coastal Law Journal 355-359 at 358.

134 The UNEP Governing Council/Global Ministerial Environment Forum, at its twentyfourth session in February 2007, decided to establish an ad hoc open-ended working group to review and assess options for enhanced voluntary measures in relation to mercury as well as options for new or use of existing international legal instruments. The working group is to report to the Council/Forum at its twenty-fifth regular session in 2009. See Governing Council of UNEP, Proceedings of the Governing Council/Global Ministerial Environment Forum at its twenty-fourth session, UNEP/GC/24/12, Decision 24/3 (Chemicals management), online: <http://www.unep.org/gc/gc24/working_documents.asp>.

135 Further evolution in international environmental governance has been the subject of considerable international dialogue with a spectrum of options, including strengthening UNEP, upgrading UNEP into a specialized agency, establishing a new UN Environment Organization and forming a new umbrella organization for the environment and sustainable development. See: Decisions Adopted by the Tenth Special Session of the Governing Council/Forum and the Summary of the President of the Discussions of Ministers and Heads of Delegation at the Tenth Session of the Council/Forum (Advance Copy) (UNEP, 5 March 2008). Also see, Proceedings of the Council/Forum at its twenty-fourth session, op. cit., supra note 134, Decision 24/1 (Implementation of decision SS.VII/1 on international environmental governance). 136 Terttu Melvasalo, "Perspectives and Experience of the UNEP Regional Seas Programme", in C. Thia-Eng, G. Kullenberg and D. Bonga (eds.), Securing the Oceans: Essays on Ocean Governance- Global and Regional Perspectives, (Quezon City, Philippines, GEF/UNDP/IMO Regional Programme on Building Partnerships in Environmental Management for the Seas of East Asia (PEMSEA) and The Nippon Foundation, 2008) 229-249 at 230. 
network of regional organizations which focus on particular seas. Many efforts have been highly successful, and it proclaims itself UNEP's most significant achievement in the last thirty years. ${ }^{137}$ It now plays a key role in implementing the GPA.

The first regional programme was established in 1975 for the Mediterranean and, as noted earlier, the RSP currently covers 18 regional seas with participation by 140 countries. ${ }^{138}$ Thirteen of the regional programmes were established under UNEP's auspices, ${ }^{139}$ while five others have an independent partnership status. ${ }^{140}$ Although the latter are not formally under the aegis of UNEP, they participate in regional seas activities, meetings and policy discussions, and support the RSP. These independent programmes are viewed as significant partners in the protection and restoration of the marine and coastal environment. ${ }^{141}$ Collectively these programmes are referred to as Regional Seas Conventions and Action Plans (RSCAP).

Most of the programmes are based on a convention agreed to by states in the region, often with associated protocols for specific issues. However, some are carried out under other arrangements. ${ }^{142}$

Regional action plans are the heart of the RSP. They are developed by the regional programmes to address the specific environmental, economic, social

137 United Nations Environment Programme, Regional Seas Programme, online: <http:// www.unep.org/regionalseas/About/default.asp $>$.

${ }_{138}$ A list of countries can be found at: <http://www.unep.org/regionalseas/Programmes/ Participating_Countries/default.asp $>$.

139 They are the Black Sea, Wider Caribbean, Eastern Africa, East Asian Seas, ROPME Sea Area (Arabian/Persian Gulf), Mediterranean, North-East Pacific, North-West Pacific, Red Sea and Gulf of Aden, South Asian Seas, South-East Pacific, Pacific, and Western Africa. UNEP directly administers six of these programmes: Caribbean, East Asian Seas, Eastern Africa, Mediterranean, North-West Pacific, and Western Africa. The remaining programmes are served by other regional organizations, and their financial and budgetary services are managed by the programmes themselves. UNEP Regional Seas Programme, UNEP Administered Programmes, online: <http://www.unep.org/regionalseas/Programmes/UNEP_Administered_Programmes/ default.asp>.

${ }_{140}$ UNEP, Regional Seas Partnerships for Sustainable Development (Nairobi, UNEP, 2005), p. 2. The partner programmes are Antarctic, Arctic, Baltic Sea, Caspian Sea and North-East Atlantic. 141 UNEP Regional Seas Programme, Independent Programmes, online: <http://www.unep. org/regionalseas/Programmes/Independent_Programmes/default.asp >.

${ }_{142}$ For a list of the programmes based on conventions see UNEP, Regional Seas Partnerships for Sustainable Development, op. cit., supra note 140, at 56-57. The East Asian Seas, NorthWest Pacific, South Asian Seas and the Arctic programmes operate under action plans. Ibid. See also David L. VanderZwaag, Overview of Regional Cooperation in Coastal and Ocean Governance in Thia-Eng et al., op. cit., supra note 136, 197-228 at 200-201. Whether regions without treaties should develop them is a matter of debate. Ibid. at 208. 
and political realities in their areas. Most plans include provisions for assessment of environmental conditions, including monitoring, research and other scientific studies. Social and economic factors may be assessed, along with the state of national legislation and its implementation. Each regional programme also includes a wide range of cooperative environmental management actions aimed at the resource and the activities affecting it. In addition, legal frameworks and institutional arrangements are spelled out in the plan. Finally, financial arrangements are addressed. UNEP and other entities typically provide some initial financing to programmes, but the governments participating in a regional programme are expected to assume financial responsibility. Regional trust funds may be established for this purpose. ${ }^{143}$

UNEP's Regional Seas Branch in Nairobi coordinates the various programmes. It describes its major role as assisting the RSPs "to fulfill their responsibilities towards the priorities identified in relevant UNEP Governing Council Decisions, to contribute to reaching the relevant targets of Agenda 21, the WSSD Plan of Implementation and the Millennium Development Goals, and in reconciling global conservation priorities with the realities of implementation at the regional level." ${ }^{144}$ Officials in Nairobi work with the secretariats, typically Regional Coordination Units (RCUs), often aided by Regional Activity Centres (RACs) which report to the RCUs. These regional entities directly oversee the implementation of the programmes and the regional action plans. ${ }^{145}$

In its early years of existence the RSP was generally focused on issues related to the deep ocean. When the UN LOSC and other international environmental conventions came into effect, the RSP provided a mechanism for assisting in their implementation. Over time it was recognized that many critical resources occurred in the coastal areas, and these resources were especially threatened by human activities, including fishing, and coastal development. Thus coastal management and protection gained focus. ${ }^{146}$ When the GPA was

143 UNEP Regional Seas Programme, Regional Seas Action Plans, online: <http://www.unep. org/regionalseas/programmes/actionplans/default.asp $>$.

${ }_{144}$ UNEP Regional Seas Programme, The Regional Seas Programmes, online: <http://www. unep.org/regionalseas/programmes/default.asp>.

145 UNEP Regional Seas Programme, About, online: <http://www.unep.org/regionalseas/about/ default.asp $>$.

146 "Although there is still an interest in levels of contamination in the open ocean and in major oceanic processes, the danger of the open ocean becoming severely polluted is now considered to be less acute, and it is evident that existing problems, and the first effects of new ones, are most likely to arise in waters close to land." UNEP: Achievements and Planned Development of UNEP's Regional Seas Program and Comparable Programs Sponsored by Other Bodies, UNEP Regional Seas Reports and Studies No. 1. (UNEP, 1982), Introduction. 
established in 1995 to grapple with land-based sources of coastal and ocean pollution, the RSPs were again available to support its implementation.

The RSP now identifies as key issues, in addition to ecosystem and biodiversity protection, pollution from ships and oil spills, marine litter, the environmental pressure on small island developing states, land-based sources of pollution and coastal area management. ${ }^{147}$ Land-based sources of pollution play an especially important role in the RSP due to strong linkages with the GPA. They are, however, some of the most difficult to deal with.

\section{Progress in Regional Seas Implementation of the GPA}

A report on implementation of the GPA at the regional level, ${ }^{148}$ prepared for IGR-2 in 2006, summarized the status of regional legal developments to address land-based sources of pollution and activities (LBSA). Six regions have developed protocols to specifically address LBSA, namely, the Black Sea, Mediterranean Sea, Red Sea and Gulf of Aden, ROPME Sea Area, South-East Pacific, and the Wider Caribbean. ${ }^{149}$ Only two protocols are post-GPA instruments, those for the Wider Caribbean and the Red Sea and Gulf of Aden. ${ }^{150}$ Two regions, the Baltic and North-East Atlantic, have annexes dealing with land-based sources of pollution. ${ }^{151}$ Three regions, the Caspian Sea, Eastern Africa and West and Central Africa, are developing LBSA protocols, ${ }^{152}$ while the Black Sea region is in the process of revising and updating its LBSA protocol. ${ }^{153}$

While many regions have general action plans or programmes that include pollution from land-based activities as well as other activities, ${ }^{154}$ five regions have developed regional programmes of action focusing purely on tackling marine pollution from land-based activities. Those regions include the Arctic,

${ }^{147}$ UNEP Regional Seas Programme, Key Issues, online: <http://www.unep.org/regionalseas/ Issues/default.asp>.

$148 \mathrm{UNEP} / \mathrm{GPA}$, Implementation of the GPA at regional level: The role of regional seas conventions and their protocols (The Hague, UNEP/GPA, 2006) [Regional Implementation Report].

149 Ibid. at 8.

150 Ibid.

151 Ibid.

152 Ibid.

153 Ibid. at 9. The Draft Revised Protocol for the Protection of the Black Sea Against Pollution from Land-based Sources and Activities is available online: <http://www.blacksea-commission. org/OfficialDocuments/ DraftRevProtocolOnLbs.htm>.

${ }^{154}$ For a listing, see Regional Implementation Report, op. cit., supra note 148, at 17, Table 2 "Status of regional seas action plans and programmes specific to LBSA." 
East Asian Seas, Mediterranean, Red Sea and Gulf of Aden and the SouthEast Pacific. ${ }^{155}$

The six LSBA protocols display considerable variations which were also summarized in the report on the implementation of the GPA at the regional level. For example, the landward and geographical scope varies considerably. The amended Mediterranean Protocol applies to the hydrological basin of the sea while the South-East Pacific Protocol only covers the area up to the freshwater limit. ${ }^{156}$ Other differences relate to scope of application (specific toxic substances, sources of pollution and activities covered), guiding principles, environmental management techniques, environmental standards, compliance and reporting requirements, and specific controls for the nine source categories set out in the GPA. ${ }^{157}$

The report also highlighted the pollution areas where regional action programmes were giving relatively little attention or a low priority. Those areas include radioactive substances, heavy metals, sediment mobilization, litter, and physical alteration and destruction of habitats. ${ }^{158}$

While a detailed examination and comparison of regional sea approaches to addressing LBSA is beyond the scope of this paper, ${ }^{159}$ regional land-based pollution obligations tend to remain general and environmental standards relatively weak. ${ }^{160}$ Common weaknesses include limited lists of substances to be phased out or prohibited, adoption of the very malleable pollution control concepts of best available technologies and best environmental practices, and an over-emphasis on pollution control through national permit authorization rather than pollution prevention. ${ }^{161}$

A major progressive breakthrough in regional cooperation for addressing coastal activities occurred in January 2008 with the adoption of the Protocol on Integrated Coastal Zone Management in the Mediterranean. ${ }^{162}$ The Protocol, which is likely to be a model for other regions, requires each Party to further strengthen or formulate a national strategy for integrated coastal zone management and coastal implementation plans and programmes. ${ }^{163}$ The Pro-

\footnotetext{
155 Ibid.

156 Ibid. at 11.

157 Ibid. at 8-15.

158 Ibid. at 24-27.

159 For a detailed comparative review, see Hassan, op. cit., supra note 7, 103-147.

160 Regional Implementation Report, supra op. cit., note 148, at 12.

161 See VanderZwaag, supra op. cit., note 142, at 215.

162 Protocol on Integrated Coastal Zone Management in the Mediterranean (21 January 2008), online: <http://www.cidce.org/pdf/PROTOCOLE\%20(ANGLAIS).pdf>.

163 Ibid. at Art. 18.
} 
tocol calls for the development of a Mediterranean Strategy for Integrated Coastal Zone Management ${ }^{164}$ and sets out guiding principles for integrated coastal zone management including, among others, the ecosystem approach, sustainable development, public participation and transparency. ${ }^{165}$ Parties are required to establish "no construction" zones above the highest winter waterline which may not be less than 100 metres in width, with a few exceptions. ${ }^{166}$

At the Ninth Global Meeting of the Regional Seas and Action Plans in 2007, strategic directions for 2008-2012 were adopted, ${ }^{167}$ many supportive of GPA implementation. Participants agreed to contribute to the implementation of the Beijing Declaration, especially the development and implementation of protocols addressing land-based pollution sources and activities. ${ }^{168}$ The need to implement the ecosystem approach in integrated marine and coastal management was emphasized ${ }^{169}$ and participants agreed to promote cooperation in formulating regional climate adaptation strategies. ${ }^{170}$ They also pledged to facilitate mainstreaming of regional sea activities into national development and economic development processes. ${ }^{171}$ To implement the strategic directions, RSCAP governing bodies would endeavour to, among other actions, build on the Bali Strategic Plan for Technology Support and Capacitybuilding ${ }^{172}$ to enhance regional and national technical, administrative, legal and financing capacities related to coastal and marine management. ${ }^{173}$

\section{Ibid. at Art. 17.}

165 Ibid. at Art. 6.

166 For example, if projects are in the public interest. Ibid. at Art. 8.

167 UNEP, Global Strategic Directions for the Regional Seas Programmes 2008-2012: Enhancing the Role of the Regional Seas Conventions and Action Plans, UNEP (DEPI)/RS.9/6 (31 October 2007) [Strategic Directions], online: <http://www.unep.org/regionalseas/globalmeetings/9/SD_ New/Final Strategic Directions 2008 2012.pdf $>$.

168 Ibid. at pt. III, para. 2.

169 Ibid. at para. 5.

170 Ibid. at para. 6 .

171 Ibid. at para. 9.

172 The Bali Strategic Plan, adopted by the UNEP Governing Council in decision 23/1 in February 2005, seeks to guide UNEP towards better meeting developing country capacitybuilding and technology support needs. Online: <http://www.unep.org/GC/GC23/documents/ GC23-6-add-1.pdf>. For a review of implementation, see Governing Council of the United Nations Environment Programme, Report of the Executive Director, International Environmental Governance, Addendum, Implementation of the Bali Strategic Plan for Technology Support and Capacity-building, UNEP/GC/24/3/Add.1 (6 December 2006), online: <http:// www.unep.org/GC/GCSS-IX/Documents/K0584592-IX-3-Add1.doc>.

\footnotetext{
${ }_{173}$ Strategic Directions, op. cit., supra note 167, at pt. IV, para. 13.
} 


\section{Regional Challenges}

The challenges facing regional implementation of the GPA, largely parallelling the challenges facing global and national implementation discussed above, ${ }^{174}$ are numerous. They include, among others, limited financial and human resources, lack of political priority and will to effectively address LBSA, and limited development and ratification of LBSA protocols.

\section{Limited Financial and Human Resources}

Besides the limited funding available to the RSP, financial and human resource constraints continue to hinder regional implementation of the GPA. Although a RSP may receive initial "catalytic" funding from UNEP, it is expected to find and administer its own source of financing. As noted earlier, this is typically done through a trust fund administered by the secretariat of the programme. Funding comes from the states themselves, along with UN and other agencies, the GEF, and other sources, both public and private. It may involve grant and matching funds, and complex arrangements. ${ }^{175}$ For example, member states may pay the costs of the regional secretariat, with contributions scaled to each country's economic situation, but rely on lead countries or private funding to pay for individual projects. ${ }^{176}$ Obviously, there are some RSPs which have more stable and substantial funding due to the participation of richer, more developed countries.

Programme secretariats' roles include collecting and disseminating data on a regional basis, providing training and advice (especially technical), developing guidelines, assisting with development of NPAs, and facilitating regional cooperation and other ongoing regular activities. ${ }^{177}$ Programme secretariats are especially susceptible to financing inconsistencies since they typically have staff and expenses that are relatively fixed and work that must be carried out from year to year. This may also be true for some programme implementation, although many activities are set up and funded as discrete projects with specific time spans. ${ }^{178}$

\footnotetext{
174 See text accompanying note 105, supra.

175 UNEP, Financing the Implementation of Regional Seas Conventions and Action Plans: A Guide for National Action, UNEP Regional Seas Reports and Studies No. 189 (UNEP, Nairobi, 2006), at 4-11.

176 Ibid. at 5.

177 Ibid. at 6. UNEP/GPA, Protecting coastal and marine environments from land-based activities: A guide for national action. (UNEP/GPA, the Hague, 2006), at 45.

178 The Caribbean Environmental Programme is reported to have left a key sub-programme position unfilled for 15 years due to insufficient funding. UNEP, op. cit., supra note 175 at 7 .
} 
UNEP, in a recent report, noted the obstacles that limited availability of financing raises for environmental protection. The funding shortfall may be due to the failure of member states to pay their shares, the lack of private contributions, the inability to adequately employ user fees and other economic measures, or to obtain payments through enforcement measures. ${ }^{179}$ Trying to achieve a regional approach may be complicated by the differing economic and developmental status of the participating countries. For developing countries, funding for infrastructure, that is, water supply, sewage treatment and other utilities, is likely to be the main expenditure necessary to protect the environment. Borrowing is typically necessary for these types of projects, with repayment made from user fees. But these countries may already have high levels of debt, and even if they secure financing, they would have difficulty servicing the debt, especially since realistic user fees are likely to be hard to impose and collect. ${ }^{180}$ Indeed, although countries may invest far less in environmental protection than is necessary, it may still consume a significant portion of their financial resources. Recent data indicate that some developing countries and countries in transition are spending as much as 2.5 per cent of their GDP on environmental activities, but simply do not have sufficient funds. ${ }^{181}$ Thus financial arrangements must, like the programme as a whole, be tailored to the realities of individual states. ${ }^{182}$ Most countries are hampered by a lack of financing adequate to allow planning and implementation of concrete actions to protect the marine environment from land-based sources of pollution. ${ }^{183}$

In addition to funding difficulties, many of the RSPs may face organizational difficulties due to understaffed secretariats, which cannot adequately deal with the myriad of agreements and tasks which they must handle and the many agreements and plans with which they must cope. Often, the distance between states participating in a RSP is itself an obstacle. Travel and associated costs can be significant, even among neighbouring states. It is even more costly and time-consuming when the states are islands where officials and other participants must travel by boat or air. An example is the South Pacific, where distances are extreme and air transport expensive and often inconvenient. While telephone, email and video links are useful and can

\footnotetext{
179 Ibid. at 13.

180 Ibid. at 14 .

181 UNEP/GPA, Domestic Resource Mobilization for the Implementation of the Global Programme of Action, online: <http://www.gpa.unep.org/content.html?id=268\&ln=6>.

182 UNEP, supra note 175 at 13.

183 Ibid. at 53.
} 
compensate to some extent, these are not always either available or a useful substitute.

A more serious problem is frequently the lack of both staff and other resources to carry out the activities called for in the action plan. Many states, especially the smaller and/or developing states, have become parties to a number of multilateral environmental agreements, covering a broad range of topics. Most require at least some technical expertise in order to establish, implement, monitor and-it is hoped-enforce their requirements. Yet smaller states have limited populations, they often lag in educational accomplishments, and if individuals do obtain technical expertise and education, they may leave the state for more lucrative positions. This is especially problematic for GPA implementation, since the activities can span a broad range of issues, from sewage treatment and overland runoff to air pollution and petroleum wastes, and require extensive cooperation.

\section{Limited Political Priority and Will}

In addition to a lack of resources, there may not always be the political will necessary to implement the RSP and GPA. ${ }^{184}$ Programmes are often costly, imposing additional and unwelcome burdens on governments and citizens. In some cases it may be necessary to restrict activities on which individuals rely for their livelihoods, such as certain fishing practices. If the public displeasure is sufficient, officials may be quite reluctant to take controversial steps. They may agree to conventions and plans, but fail to follow through. Even if the officials in good faith follow through on programmes at a state level, regional cooperation may still be difficult. And if a threat is identified, it may take a substantial amount of time for the programme officials at both the state and regional levels to assess its severity, devise measures to address it, agree on those measures, and implement them. ${ }^{185}$ Regional programmes can be even more stressed when the countries involved in the programme do not have the best of political relations.

A case in point is the Caspian, where debates over boundaries and natural resources are unresolved. The Caspian Environment Programme (CEP), which is independent of UNEP, was established in 1999 by the five countries bordering the Sea, Azerbaijan, Iran, Kazakhstan, Russia and Turkmenistan. ${ }^{186}$ Although

184 On the challenge of lack of political will, see VanderZwaag, op. cit., supra note 142, at 208-9 and P.M. Hass, "Evaluating the Effectiveness of Marine Governance," in Thia-Eng et al., op. cit., supra note 136, 253-282 at 256.

185 Terttu Melvasalo, op. cit., supra note 136 at 241.

186 UNEP, Regional Seas Programme, Caspian Sea, <http://www.unep.org/regionalseas/ Programmes/Independent_Programmes/Caspian_Sea/default.asp $>$. 
the pollution problems are extensive, resulting in part from more than a century of oil exploitation, the program is small and the countries themselves suffer both economic and political problems. In its report for 2004-2007, the CEP notes candidly that in spite of progress in some areas, it has had limited success in others. The states' ministries of environment lack political power, and difficulties in educating the public and encouraging participation by civil society have also been noted. ${ }^{187}$

\section{Limited Development and Ratification of LBSA Protocols}

Not all regions have developed legally binding commitments to control landbased marine pollution and activities, and ratification of existing LBSA protocols has been problematic. The LBSA protocols for the Wider Caribbean and Red Sea and Gulf of Aden have not yet entered into force. ${ }^{188}$ The modernization amendments to the Mediterranean LBSA protocol, adopted in March 1996, only entered into force in May 2008. ${ }^{189}$ The slow rate for ratification of Mediterranean environmental agreements ${ }^{190}$ has even caused one author to question whether a legally binding approach is advisable. ${ }^{191}$

187 UNEP, Implementing the Global Regional Seas Strategic Directions 2004-2007, Compilation of Summary Reports of the Regional Seas Conventions and Action Plans, Caspian Environment Programme, UNEP (DEPI)/RS.9.5 (22 October 2007), online: <http://www.unep.org/ regionalseas/globalmeetings/9/wp.05_Compilation_Reports_Implementation_of_Strategic_ Directions.pdf>. When the CEP attempted to create a regional stakeholder network, its results were less than stellar due to the novelty of the idea of public engagement in a world that has been traditionally the domain of the governments and scientists. Ibid.

188 Regional Implementation Report, op. cit., supra note 148, at 8-9.

189 The amended Protocol for Protection of the Mediterranean Sea against Pollution from Land-based Sources and Activities was adopted 7 March 1996 at Syracuse, Italy. UNEP Mediterranean Action Plan for the Barcelona Convention, Protocols, online: <http://www.unepmap.org/index.php? module $=$ content $2 \&$ catid $=00 / 00 / 00 />$.

${ }_{190}$ The Protocol on the Prevention of Pollution of the Mediterranean Sea by Transboundary Movements of Hazardous Wastes and Their Disposal, adopted 1 October 1996, only entered into force 19 January 2008, while the Protocol for the Protection of the Mediterranean Sea against Pollution Resulting from Exploration and Exploitation of the Continental Shelf and the Seabed and the Subsoil, adopted 14 October 1994, has not yet entered into force. Nor has the amended protocol for the Prevention and Elimination of Pollution of the Mediterranean Sea by Dumping of Ships and Aircraft or Incineration at Sea, adopted 10 June 1995, entered into force. Ibid.

191 See Suh-Yong Chung, "Is the Convention-Protocol Approach Appropriate for Addressing Regional Marine Pollution? The Barcelona Convention System Revisited," (2004) Penn State Environmental Law Review 85-103. On the pros and cons of a legally binding approach, see VanderZwaag, op. cit., supra note 142, at 208. 


\section{Conclusion}

Since its adoption in 1995, the GPA has pushed countries and regions to address the multiple sources of land-based marine pollution and the pressures of coastal activities. Over 70 countries are implementing the GPA through NPAs or related processes. UNEP's RSP continues to champion GPA implementation at the regional level with one of its strategic aims to further enhance the development and implementation of LBSA protocols.

Although many GPA-related meetings have been held and reams of paper on GPA implementation have been issued, the conceptual and aspirational efforts have faced numerous challenges in moving from words to effective practice. ${ }^{192}$ Those challenges, among others, include limited financing and human resources, lack of political priority and will, limited adoption and implementation of global and regional agreements relating to LBSA, the huge scale and breadth of human uses that have to be addressed, and the limits surrounding a non-legally binding approach.

The GPA has not been able to substantially curb four of the most serious sources of marine degradation. Worsening conditions have been reported for sewage, nutrients, marine litter and physical alteration and destruction of habitats.

While the global community currently seems content to putter along aboard the voluntary "GPA raft", more effectively countering the complex array of human uses on land affecting the oceans may largely depend on a broader fleet of initiatives. They include, among others, taking a more proactive and precautionary approach to managing chemicals through a comprehensive chemicals convention; adopting a global and perhaps additional regional agreements on heavy metals; forging global agreement on further greenhouse gas emission controls and reductions; and furthering international environmental governance reforms, such as a strengthened UNEP. A firmer "hull" for the GPA in the form of a global legally binding instrument on land-based marine pollution may also need to be considered. The GPA does not sail alone and high tides in global and regional governance have yet to be reached.

192 Regarding the need to address the governance gaps, see A. Alm, "The Wider Caribbean" in Thia-Eng et al., op. cit., supra note 136, 539-562 at 559. 